\title{
MANAJEMEN PENINGKATAN MUTU MADRASAH \\ BERBASIS KEMITRAAN TRITUNGGAL \\ (Studi Multisitus pada Tiga Madrasah Ibtidaiyah Sasaran Program Kemitraan \\ Pendidikan Australia - Indonesia (KPAI) di Kabupaten Malang)
}

\author{
${ }^{1}$ Aan Fardani Ubaidillah, ${ }^{2}$ Isna Nurul Inayati \\ ${ }^{1,2}$ Pendidikan Guru Madrasah Ibtidaiyah - Fakultas Ilmu Keislaman \\ Universitas Islam Raden Rahmat Malang \\ Jalan Raya Mojosari No.2, Kepanjen - Malang \\ Email: ${ }^{1}$ afubaidillah@gmail.com, ${ }^{2}$ tsani_kids@yahoo.com
}

\begin{abstract}
This research is intended to assess the management of madrasah quality improvement through a trinity partnership scheme for Madrasah target of Australia Indonesia Education Partnership (KPAI) program in Malang Regency. The research focused on three things: (1) legal base of trinity partnership, (2) construction of madrasah quality improvement management based on trinity partnership, and (3) forms of management activities of madrasah quality improvement based on trinity partnership. This research uses qualitative approach of multisitus study method. This research targeted three Madrasah Ibtidaiyah (MI) that became the target of KPAI program namely MI Bustanul Uqul, MI Raden Patah, and MI Thoriqul Huda. The results showed that (1) the legal basis for the trinity partnership program is based on the Decision of Director of Madrasah Education of Directorate General of Islamic Education of the Ministry of Religious Affairs of the Republic of Indonesia, Number Dj.I/Dt.II/4 /Hm.01/578.A/2014, ( 2) madrasah-based quality improvement management based on trinity partnership consist of grant funding scheme, mentoring, training and additional end-of-program assessment by independent mentor, trainer, and assistant recruited openly by Madrasah Development Center ( MDC) as an extension of the KPAI at the district / provincial level, and (3) more partnership forms are dominated by non-physical activities through mentoring and training that includes the Effective Madrasah Development (EMD) and Madrasah Based Management (MBM) which subsequently gave birth mentoring program (mentoring) preparation of Madrasah Self-evaluation and Work Plan Madrasah (RK M), followed by further training and facilitation in the form of healthy living program, preparation and development of madrasah curriculum, PAIKEM, library capacity building program, and administration management and madrasah finance.
\end{abstract}

\begin{abstract}
Abstrak
Penelitian ini dimaksudkan untuk mengkaji manajemen peningkatan mutu madrasah melalui skema kemitraan tritunggal bagi madrasah sasaran program Kemitraan Pendidikan Australia Indonesia (KPAI) di Kabupaten Malang. Penelitian difokuskan pada tiga hal: (1) landasan hukum kemitraan tritunggal, (2) konstruksi manajemen peningkatan mutu madrasah berbasis kemitraan tritunggal, dan (3) bentuk-bentuk kegiatan manajemen peningkatan mutu madrasah berbasis kemitraan tritunggal. Penelitian ini menggunakan pendekatan kualitatif metode studi multisitus, Penelitian ini menyasar tiga Madrasah Ibtidaiyah (MI) yang menjadi sasasaran program KPAI yakni MI Bustanul Uqul, MI Raden Patah, dan MI Thoriqul Huda. Hasil penelitian menunjukkan bahwa (1) landasan hukum atas program kemitraan tritunggal
\end{abstract}


dilandasi oleh Keputusan Direktur Pendidikan Madrasah Direktorat Jenderal Pendidikan Islam Kementerian Agama Republik Indonesia, Nomor Dj.I/Dt.I.I/4/Hm.01/578.A/2014, (2) manajemen peningkatan mutu madrasah berbasis kemitraan tritunggal terdiri atas skema pemberian dana pendukung (hibah), pendampingan (mentoring), pelatihan (training) serta tambahan penilaian endline program oleh mentor, trainer, dan asessor independen yang direkrut secara terbuka oleh Madrasah Development Center (MDC) sebagai kepanjangan tangan KPAI di tingkat distrik/propinsi, dan (3) bentuk-bentuk program kemitraan lebih didominasi oleh penyelenggaraan kegiatan-kegiatan non-fisik melalui pendampingan dan pelatihan yang mencakup Pengembangan Madrasah Efektif (PME) dan Manajemen Berbasis Madrasah (MBM) yang selanjutnya melahirkan program pendampingan (mentoring) penyusunan Evaluasi Diri Madrasah (EDM) dan Rencana Kerja Madrasah (RKM), dilanjutkan berbagai pelatihan dan pendampingan lanjutan berupa program hidup sehat, penyusunan dan pengembangan kurikulum madrasah, PAIKEM, program peningkatan kapasitas perpustakaan, serta pengelolaan adinistrasi dan keuangan madrasah.

Kata kunci: Australia Aid, Madrasah Development Center, Kemitraan Tritunggal Madrasah Ibtidaiyah

\section{A. PENDAHULUAN}

Madrasah adalah bentuk satuan pendidikanyang otoritanya berada di bawah naungan Kementerian Agama Rebuplik Indonesia. Madrasah berfungsi melaksanakan pendidikan formal maupun non-formal yang keberadaanya diakui dan setara dengan bentuk sekolah (yang lazimnya dikenal dengan sebutan "sekolah umum") yang dinaungi oleh Kementerian Pendidikan dan Kebudayaan Republik Indonesia. Madrasah Ibtidaiyah sendiri merupakan bentuk satuan pendidikan yang berada pada jalur pendidikan formal di jenjang pendidikan dasar. Keberadaannya setara dengan Sekolah Dasar sebagaimana ditegaskan dalam Bab IV Bagian Kedua tentang Pendidikan Dasar dimana pada Pasal 17 ayat (2) Undang-Undang Republik Indonesia Nomor 20 Tahun 2003 tentang Sistem Pendidikan Nasionalbahwa "Pendidikan dasar berbentuk sekolah dasar (SD) dan madrasah ibtidaiyah (MI) atau bentuk lain yang sederajat serta sekolah menengah pertama (SMP) dan madrasah tsanawiyah (MTs), atau bentuk lain yang sederajat".

Ditilik dari akar sejarahnya, keberadaan madrasah di Indonesia sejatinya lebih dahulu ada dibanding sekolah-sekolah umum. Madrasah mula-mula muncul sebagai madrasah diniyah non-formal yang berfungsi sebagai halaqoh-halaqoh keagamaan, baik yang menyatu dengan pesantren maupun yang berbasis masjid. Namun demikian, sejarah panjang perjalanan madrasah belum menjadi jaminan kemapanan mutu. Secara umum, kondisi madrasah masih jauh tertinggal dari sekolah umum. Di Jakarta yang merupakan Ibu Kota Negara misalnya, tidak satupun madrasah yang berada di lokasi strategis. jika tidak berada di bantaran sungai biasanya berada di bekas rawa-rawa (Setiawan, 2014:104). Mayoritas input 
madrasah juga umumnya bukan dari siswa-siswa sekolah favorit di jenjang sebelumnya.Padahal, menilik sejarah dan sebarannya, madrasah juga merupakan penyedia pendidikan berbasis masyarakat yang tersebar di seluruh wilayah nusantara. Saat ini di seluruh Indonesia jumlahnya mencapai 7.414 lembaga, meliputi Raudlatul Athfal (RA), Madrasah Ibtidaiyah (MI), Madrasah Tsanawiyah (MTs), dan Madrasah Aliyah (MA). Dari jumlah tersebut, sebanyak 91\% milik publik dan sisanya, 9\%, merupakan Madrasah Negeri (Setiawan, 2014:104).

Pada aspek pengelolaan, urgensi pengembangan perencanaan belum tampak mengakar pada sebagian besar madrasah swasta, terutama pada ranah Madrasah Ibtidaiyah. Hasil survey Kementerian Agama RI (dulu Departemen Agama), melalui Badan Litbang dan Diklat tahun 2010, disebutkan bahwa dari seluruh jumlah MI, MTs, dan MA yang diambil dari 5 Provinsi, hanya 21,4 \% MI yang telah membuatperencaan pengembangan sekolah/madrasah; sementara kondisi lebih baik terlaksana di MTs sebesar 45,7\% MTs dan hasil yang MA sebesar 67,8 \%. Angka untuk MI ini relatif rendah jika dibandingkan dengan MTs dan MA (Kepala Badan Penelitian dan Pengembangan Departemen Agama Republik Indonesia, 2010:2).

Data-data tersebut di atas barangkali dapat menjadi gambaran awal betapa mutu madrasah di Indonesia hari ini masih menyisakan pekerjaan rumah yang perlu segera diupayakan. Segenap usaha peningkatan mutu madrasah, utamanya dalam konteks madrasah swasta yang memiliki keleluasaan lebih sekaligus tuntutan kemandirian lebih dibanding madrasah negeri pada gilirannya kembali pada seberapa tinggi komitmen peningkatan mutu dibangun serta kreativitas dan inovasi dimunculkan. Hal ini sesungguhnya merupakan hakikat dari manajemen berbasis sekolah/madrasah sebagaiamana dijamin undang-undang. Tepatnya, jaminan tersebut nampak dalam Pasal 51 Ayat (1) Undang-Undang Republik Indonesia Nomor 20 Tahun 2003 tentang Sistem Pendidikan Nasional bahwa“yang dimaksud dengan manajemen berbasis sekolah/madrasah adalah bentuk otonomi manajemen pendidikan pada satuan pendidikan, yang dalam hal ini kepala sekolah/madrasah dan guru dibantu oleh komite sekolah/madrasah dalam mengelola kegiatan pendidikan".

Dalam praktiknya, kemandirian madrasah sebagai pelaksana pendidikan formal terdepan,dapat mengelola berbagai upaya yang diperlukan untuk meningkatkan mutu, baik melalui usaha-usaha internal maupun menggandeng pihak luar madrasah. Pemikiran ini telah mendorong munculnya pendekatan baru dalam pengelolaan pendidikan yang berbasis sekolah. Dalam konteks persekolahan, pendekatan ini dikenal dengan istilah Manajemen Peningkatan Mutu Berbasis Sekolah (School BasedQuality Management), sementara di 
lingkungan Kementerian Agama dikenal dengan istilah Manajemen Peningkatan Mutu Berbasis Madrasah yang selanjutnya disebut MPMBM (Buna'i, 2006:186).

Minimnya dana, lemahnya soft skills sumber daya manusia, dan kurangnya insisiatif di madrasah swasta adalah kondisi umum yang dihadapi tidak saja oleh Kementerian Agama, namun juga para Kepala Madrasah dalam upaya-upaya peningkatan mutu. Adanya berbagai bantuan seperti BOS dan hibah-hibah lainnya pada gilirannya juga acapkali bersifat konsumtif karena hanya memberikan "ikan" semata, bukan "alat pancing"/stimulan partisipatif yang bermakna dalam memberikan nilai tambah baik fisik maupun non fisik bagi madrasah.

Salah satu momentum penting peningkatan mutu madrasah melalui skema hibah hadir pada tahun 2011 melalui komitmen pemerintah australia untuk membantu peningkatan mutu pendidikan di Indonesia melalui program Australia Aid. Program tersebut diwujudkan melalui bentuk kemitraan yang selanjutnya diberi nama Kemitraan Pendidikan Australia-Indonesia (KPAI) yang menyasar sekolah di lingkungan Kementerian Pendidikan dan Kebudayaan serta madrasah di lingkungan Kementerian Agama.

Melalui program ini, 1500 madrasah swasta di 14 provinsi sasaran diberikan programprogram peningkatan mutu pendidikan, terutama program-program non-fisik yang bertujuan meningkatkan kapasitas personil madrasah. Realisasinya diwujudkan melalui berbagai jenis pelatihan untuk memperkuat kualitas 8 standar nasional pendidikan pada masing-masing madrasah. Pelatihan yang diberikan antara lain pengembangan madrasah efektif, penyusunan RKM/RKAM, pengembangan kurikulum, pembelajaran aktif (PAIKEM), hidup sehat, perpustakaan, serta administrasi dan keuangan. Pelatihan ini diselenggarakan oleh lembaga mitra pada masing-masing provinsi sasaran, yang disebut dengan SNIP (Sub-National Implementing Partner).

Dalam prosesnya, selama masa kontrak dan proses perwujudan program-program tersebut, seluruh madrasah sasaran didampingi oleh mentor. Tugas utama mentor adalah mendampingi madrasah sasaran memenuhitagihan pelatihan serta memastikan penggunaan dana hibah oleh madrasah sesuai dengan mekanisme yang telah ditentukan (Tholchah, 2015:92-93).

Selain program non-fisik, Madrasah juga diperbolehkan mengalokasikan sedikit anggaran dari dana hibah untuk melakukan renovasi ringan misalnya tamanisasi, sanitasi, pengecatan, renovasi toilet, renovasi kelas, gapura, pagar, dan lain sebagainya sesuai skala prioritas berdasarkan EDM dan RKM/RKAM yang disusun madrasah sebagai hasil pelatihan dan mentoring. Alokasi untuk program fisik ini rata-rata menuntut adanya dana sharing dari tiap madrasah meskipun tidak banyak. Program-program fisik ini kebanyakan didominasi oleh tagihan hasil pelatihan hidup sehat dimana madrasah didorong untuk menerapkan pola 
hidup sehat baik dari sisi kebersihan lingkungan, toilet, optimalisasi fungsi, ketersediaan fasilitas cuci tangan, pengelolaan sampah, makanan sehat (yang dijual di kantin), serta pengelolaan sarana prasarana madrasah.

Secara umum, program-program kemitraan sebagaimana telah penulis kemukakan, mencakup 3 komponen.Komponen pertama ditujukan bagi konstruksi untuk Kementrian Pendidikan dan Kebudayaan serta Kementerian Agama. Komponen keduaditujukan untuk kapasitas distrik peningkatan distrik. Di lingkungan Kementerian Agama, khususnya komponen kedua untuk wilayah Jawa Timur, dikelola melalui lembaga semi-otonom yang berada di Kantor Kementerian Agama Wilayah di tiap Propinisi, yakni Madrasah Development Center (MDC).

Adapun, komponen ketiga dikhususkan untukakreditasi di kementrian agama yang pembahasannya berfokus pada peningkatan 8 standar nasional pendidikan yang bermuara pada akreditasi masing-masing madrasah sasaran program. Target penerima bantuan AusAID di komponen 3 SSQ ini ialah madrasah swasta yang belum terakreditasi atau tidak lolos akreditasi yang memiliki komitmen untuk terus maju (Risasta, 2015:6). Madrasah Ibtidaiyah (MI) Bustanul Uqul, MI Raden Patah, dan MI Thoriqul Huda adalah tiga MI yang dipandang memenuhi kriteria untuk diikutkan program tersebut yang kemudian direkomendasikan oleh MDC Jawa Timur kepada KPAI pada tahun 2014 sebagai sasaran komponen 3 SSQ dari total 416 Madrasah sasaran(Tholchah, 2016:37).

Dalam realisasi di lapangan, seluruh madrasah sasaran program, termasuk MI Bustanul Uqul, MI Raden Patah, dan MI Thoriqul Huda diberikan bantuan dana sebesar AUS\$ 10.000 atau senilai dengan Rp 100.000.000,00. Dana tersebut dicairkan dalam tiga tahap, yaitu \$ 1000 setelah penandatanganan kontrak sebagai madrasah sasaran, $\$ 7000$ setelah proposal penggunaan disetujui oleh komponen 3, serta \$2,000 dicairkan setelah laporan penggunaan dana yang dua tahap disetujui (Tholchah, 2015:93, 2016:37).

Bagi Madrasah sasaran sebagaimana informasi yang peneliti terima, dana tersebut sesungguhnya tidaklah besar dengan banyaknya tuntutan program dan tagihan pelatihan yang harus dipenuhi guna menunjang capaian nasional terhadap 8 komponen standar nasional pendidikan.AusAID dan Kementerian Agama (tim KPAI) sesungguhnya juga menyadari hal ini sehingga program kemitraan ini sejak awal memiliki karakteristik yang spesifik, yaitu stimulan, model/piloting, peningkatan kapasitas SDM, serta mendukung sistem. Menyadari hal tersebut, tim KPAI, sejak awal mencoba mendorong agar program ini hanyalah sebagai stimulan bagi Madrasah, dimana dana hibah yang tidak besar ini diharapkan dialokasikan untuk program dan kegiatan yang memberi manfaat besar dan menarik minat pihak-pihak yang lebih luas untuk berpartisipasi dalam upaya meningkatkan kualitas madrasah. 
Program kemitraan ini selanjutnya juga hanya diharapkan sebagai model pengembangan madrasah yang di sana terdapat best practicedan lesson learn, dimana hal-hal baik yang diperoleh selama mentoring dan pelatihan dapat terus dilanjutkan dan pada saat yang sama jika ada kekurangan dapat dimodifikasi sedemikian rupa sehingga sesuai dengan konteks yang ada. Program kemitraan. Karena itulah tidak mengherankan jika alokasi dana lebih banyak diperuntukkan bagi penyelenggaraan program-program pelatihan dibanding program-program yang bersifat fisik.

Dari ulasan-ulasan konteks tersebut, nampak bahwasanya program-program KPAI tersebut dirancang dengan skema hibah yang memungkinkan madrasah sasaran untuk melaksanakan transformasi budaya demi menciptakan iklim kerja yang bermutu secara bertahap melalui integrasi dana hibah, pelatihan oleh trainer, dan pendampingan oleh mentor. Model ini kemudian diistilahkan dengan tritunggal. Model ini pula yang kemudian memposisikan penerima bantuan sebagai mitra, bukan sekedar donatur, termasuk perwujudan posisi mitra tersebut dengan menghadirkan trainer dan mentor dalam program-program yang dimaksudkan untuk penguatan kapasitas Sumber Daya Manusia di Madrasah.

Skema bantuan dengan pola yang demikian sesungguhnya menjadi antitesis atas: (1) pola kerjasama bermuatanbantuan konvensional/gaya lama antara donatur dengan madrasah penerima umumnya bersifat subyek-obyek, dimana penerima bantuan, dalam hal ini madrasah-madrasah hanya berposisi sebagai obyek dan cenderung bersifat pasif, dan (2) program-program bantuan pendidikan yang didapatkan oleh sebuah lembaga pendidikan, sebagaimana madrasah umumnya berorientasi pragmatis yang menjadikan nilai pemberdayaan yang memungkinkan terjadinya peningkatan mutu berkelanjutan (continous quality improvement) acapkali tidak tercapai, baik selama proses implementasi maupun pasca implementasi bantuan/kerjasama.

Tulisan ini bermaksud untuk mengkaji realisasi kemitraan tritunggal, khususnya dalam perspektif Madrasah Ibtidaiyah sasasaran bantuan. Tujuan yang ingin dicapai adalah mendapatkan gambaran (konstruksi) manajemen peningkatan mutu madrasah berbasis kemitraan tritunggal dengan fokus penelitian pada: (1) Landasan hukum kemitraan tritunggal, (2) Konstruksi manajemen peningkatan mutu madrasah berbasis kemitraan tritunggal, dan (3) Bentuk-bentuk kegiatan manajemen peningkatan mutu madrasah berbasis kemitraan tritunggal.

\section{B. METODE}

Menggunakan pendekatan kualitatif dengan metode studi multisitus, penelitian ini mengambil tiga Madrasah Ibtidaiyah (MI) yang menjadi penerima hibah program Kemitraan 
Pendidikan Australia-Indonesia (KPAI) melalui Madrasah Development Center (MDC) Propinsi Jawa Timur yakni MI Bustanul Uqul yang dan MI Raden Patah yang keduanya berada di Kecamatan Pujon, Kabupaten Malang, dan MI Thoriqul Huda yang berada di wilayah Kecamatan Wagir Kabupaten Malang. Teknik pengumpulan data menggunakan wawancara mendalam dimana Peneliti berperan sebagai Key Instrument (Informan -informan kunci adalah Kepala Madrasah, Mentor, Trainer, dan Asessor yang ditentuken bergulir dengan pendekatan purposive sampling dan snowball sampling), observasi partisipan dan studi dokumenter. Analisis data dilakukan sebanyak dua kali, yakni bersamaan dengan pengumpulan data di lapangan dan analisis pasca pengumpulan data. Data-data yang ditemukan dianalisis dua tahap, yakni analisi tiap situs, selanjutnya temuan tiap situs dianalisis lintas situs (cross-site)menggunakan teknik induksi termodifikasi untuk menarik simpulan akhir, dimana keabsahannya berpedoman pada empat kriteria: (1) kredibilitas melalui triangulasi teknik dan sumber, (2) dependabilitas, (3) konfirmabilitas, dan (4) transferabilitas.

\section{TEMUAN PENELITIAN}

1. Landasan Hukum Kemitraan Tritunggal di Madrasah Ibtidaiyah Bustanul Uqul, Madrasah Ibtidaiyah Raden Patah, dan Madrasah Ibtidaiyah Thoriqul Huda

Kemitraan tritunggal yang digagas oleh Australian AID (AusAID)di Lingkungan Kementerian Agama Republik Indonesia (Kemenag RI)yang dilaksanakan melalui 3 komponen (Kemitraan Pendidikan Ausralia-Indonesia/KPAI di tingkat pusat sebagai komponen 1/C1 Kemenag RI, Madrasah Development Center (MDC) di tingkat distrik/propinsi sebagai komponen 2/C2, serta madrasah sasaran program sebagai komponen 3/C3)dinaungi oleh landasan hukum berupa Keputusan Direktur Pendidikan Madrasah Direktorat Jenderal Pendidikan Islam Kementerian Agama Republik Indonesia, Nomor Dj.I/Dt.I.I/4/Hm.01/578.A/2014, Tanggal 23 September 2014, Perihal Penetapan Madrasah Sasaran Program Kemitraan Pendidikan Australia Indonesia Komponen 3 Akreditasi Madrasah Tahap ke-3 Tahun 2014-2015.

Sedangkan secara khusus, untuk komponen C3, dalam kasus ini Madrasah Ibtidaiyah (MI) Bustanul Uqul, MI Raden Patah, dan MI Thoriqul Huda dibuatkan masing-masing perjanjian sebagai berikut:

1) Grand Agreement deed Cadno Agreement AC43800/SSQ-Madrasah/792 Australia's Education Partnership with Indonesia, School Systems and Quality between Cadno Emerging markets (Australia) and MI Bustanul Uqul For Madrasah Block Grants From 
Australia's Education Partnership With Indonesia-Phase 3/Dana Hibah untuk Madrasah dari Kemitraan Pendidikan Australia-Indonesia Fase 3.

2) Grand Agreement deed Cadno Agreement AC43800/SSQ-Madrasah/792 Australia's Education Partnersjip with Indonesia, School Systems and Quality between Cadno Emerging markets (Australia) and MI Raden Patah For Madrasah Block Grants From Australia's Education Partnership With Indonesia-Phase 2/Dana Hibah untuk Madrasah dari Kemitraan Pendidikan Australia-Indonesia Fase 2.

3) Grand Agreement deed Cadno Agreement AC43800/SSQ-Madrasah/792 Australia's Education Partnersjip with Indonesia, School Systems and Quality between Cadno Emerging markets (Australia) and MI Thoriqul Huda For Madrasah Block Grants From Australia's Education Partnership With Indonesia-Phase 2/Dana Hibah untuk Madrasah dari Kemitraan Pendidikan Australia-Indonesia Fase 2 (Australian Aid, 2015a:3-4, 2015b:3-4, dan 2015c:3-4)

\section{Konstruksi Manajemen Peningkatan Mutu Madrasah Berbasis Kemitraan} Tritunggal di Madrasah Ibtidaiyah Bustanul Uqul, Madrasah Ibtidaiyah Raden Patah, dan Madrasah Ibtidaiyah Thoriqul Huda

Pelaksanaan program kemitraan tritunggal dimaksudkan sebagai program hibah bermakna yang bertujuan untuk meningkatkan mutu madrasah baik dalam bidang fisik maupun non fisik. Implementasi bantuan dilaksanakan secara berkala dan temporer melalui tiga skema: (1) penyaluran dana hibah sebesar AUS\$ 10.000 atau senilai dengan Rp. 100.000.000,00, yang diarahkan untuk peningkatan mutu fisik dan non-fisik (kapasitas personil madrasah), (2) pelatihan oleh mentor yang ditunjuk oleh Madrasah Development Center (MDC) Jawa Timur untuk meningkatkan kemampuan personil madrasah dalam manajemen kurikulum (KTSP 2006 dan KTSP 2013/K13), pembelajaran (aktif, inovatif, kreatif, efektif, dan menyenangkan), evaluasi (penilaian otentik), dan penyusunan borang akreditasi, dan (3) pendampingan (mentoring) oleh mentor yang ditunjuk oleh Madrasah Development Center (MDC) Jawa Timur untuk mendampingi madrasah dalam implementasi pembelanjaan dana hibah berikut laporannya, penyususnan evaluasi diri madrasah (EDM), dan selanjutnya menyusun rencana kerja madrasah (RKM/RKAM) sesuai pertimbangan kebutuhan prioritas madrasah (berdasarkan EDM).

Selain ketiganya, secara khusus, MDC juga mengadakan perekrutan dan pelatihan Asessor yang disiapkan sebagai Asessor Endline Program. Rekrutmen asessor diluar mentor dan trainer dimaksudkan untuk mengukur keberhasilan program sekaligus kesiapan madrasah sasaran dalam pengajuan akreditasi ke Badan Akreditasi Sekolah/Madrasah (BAN S/M). 
Terakreditasi atau mencapai peningkatan nilai akreditasi adalah bagian dari outcomeyang diharapkan melalui sekam kemitraan yang digagas oleh AusAID tersebut.Dalam prosesnya, asessor yang ditunjuk ditugaskan untuk mengadakan bedah instrumen akrediatasi dan simulasi akreditasi.

Berdasarkan kajian peneliti baik bersama dengan personil madrasah ada ketiga situs, dengan para trainer, para mentor, dan asessor, operasional di tingkat satuan pendidikan dalam perwujudan manajemen peningkatan mutu madrasah melalui skema kemitraan tritunggal tersebut lebih banyak menampilkan mentor sebagai personil kunci yang sangat menentukan keberhasilan program. Dalam praktiknya, selain tugas mentoring, mentor juga berperan sebagai supervisor, motivator, dan pada beberapa kesempatan kegiatan pelatihan, dihadirkan trainer yang secara khsusus dikontrak oleh MDC untuk mengisi kegiatan pelatihan Kurikulum KTSP dan K-13, Pelatihan Pembelajaran Aktif, Inovatif, Kreatif, Efektif, dan Menyenangkan (PAIKEM), serta bedah instrumen dalam rangka simulasi akreditasi.

Secara umum, dapat peneliti simpulkan pula bahwa orientasi program kemitraan ini adalah dalam rangka mewujudkan capaian standar nasional bagi madrasah sasaran yang mengedepankan proses sebagai bagian dari upaya mewujudkan budaya mutu. Akreditasi pada gilirannya adalah capaian akhir yang menjadi bagian dari target program sekaligus indikator apakah peningkatan mutu dapat terpenuhi sesuai harapan AusAID dan KPAI atau tidak. Berbeda dengan proses akreditasi yang selama ini banyak dilakukan sekolahsekolah/madrasah dengan pendekatan pragmatis, melalui program yang pelaksanaannya hampir berjalan sepanjang satu tahun melalui kemitraan ini, tiap madrasah dituntut secara bertahap untuk memenuhi delapan komponen standar nasional pendidikan melalui proses kerja sehari-hari secara bermutu melalui dampingan dari para mentor dan pelatihan dari trainer yang ditunjuk.

Konstruk manajemen peningkatan mutu oleh madrasah berbasis kemitraan tritunggal yang Peneliti temukan mencakup 6 komponen/tahapan dan 7 sub-komponen berikut:

1) Pemerintah Australia melalui $\mathrm{MoU}$ oleh Australia AID (AusAID)denganKementerian Agama Republik Indonesia dan membentuk program Kemitraan Pendidikan Australia Indonesia sebagai nama program pengganti SSQ (School Systems and Quality).

2) Penunjukan dan MoU oleh KPAI dengan Madrasah Development Center (MDC) di masing-masing propinsi sebagai pengelola program di tingkat distrik dan satuan pendidikan.

3) Penetapan Madrasah sasaran program oleh distrik (MDC Jawa Timur) dan rekomendasi ke tim KPAI Pusat.

4) Rekrutmen dan Pelatihan Mentor, Trainer, dan Asessor Endline Program oleh MDC. 
5) Penandatanganan kontrak Madrasah sasaran dan pencairan dana (tiga tahap, yaitu $\$ 1000$ setelah penandatanganan kontrak sebagai madrasah sasaran, \$ 7000 setelah proposal penggunaan disetujui oleh komponen 3 , serta \$2,000 dicairkan setelah laporan penggunaan dana yang dua tahap disetujui)

6) Implementasi di Madrasah Sasaran

a. Monitoring dan Evaluasi berkala oleh MDC,

b. Mentoring oleh Mentor (Penyususnan Evaluasi Diri Madrasah (EDM), Rencana Kerja Madrasah (RKM) berdasarkan EDM, dan pendampingan dalam implementasi serta evaluasi program bantuan dalam bentuk program-program non-fisik maupun fisik (KTSP 2006/K13, PAIKEM, Hidup Sehat, Perpustakaan, Administrasi dan Keuangan)

c. Training oleh Trainerdan pelaporannya kepada MDC Jawa Timur (KTSP 2006/K13 dan PAIKEM),

d. Asessmen akhir oleh Asessor Endline Program yang ditunjuk dalam bentuk Bedah instrumen akreditasi dan simulasi akreditasi oleh Asessor Endline dan pelaporannya kepada MDC Jawa Timur (mencakup capaian EDM, RKM/RKAM, KTSP2006/K13, Hidup Sehat, Perpustakaan, Administrasi dan Keuangan),

e. Pelaporan akhir oleh Madrasah sasaran kepada MDC Jawa Timur dengan pendampingan dari mentor,

f. Pelaporan akhir oleh MDC Kepada tim KPAI-Kemenag RI, dan

g. Pelaporan akhir oleh KPAI-Kementerian Agama Republik Indonesiakepada pemerintah Autralia melalui pengelola program Australia Aid.

Tiap tahapan dalam konstruk tersebut diarahkan sebagai program penguatan terhadap 8 komponen standar nasional pendidikan yang memang disiapkan untuk akreditasi pada akhir program sebagaimana penulis sajikan pada tabel 1. Adapun konstruksi manajemen peningkatan mutu berbasis kemitraan bermakna yang mencakup tahapan-tahapan dan pembagian peran sebagaimana telah diuraikan Peneliti sajikan dalam gambar 1 . 
Tabel 1. Matriks Penguatan Program-Program Kemitraan Pendidikan Australia

Indonesia bagi Madrasah Sasaran (MI Bustanul Uqul, MI Raden Patah, dan MI Thoriqul Huda)

\begin{tabular}{|c|c|c|c|c|c|c|c|c|c|}
\hline \multirow{2}{*}{$\mathbf{N}$} & \multirow{2}{*}{$\begin{array}{c}\text { Jenis } \\
\text { Mentoring/ } \\
\text { Pelatihan }\end{array}$} & \multicolumn{8}{|c|}{ Standar Nasional Pendidikan } \\
\hline & & Isi & $\begin{array}{l}\text { Prose } \\
\text { s }\end{array}$ & SKL & $\begin{array}{l}\text { PT } \\
\text { K }\end{array}$ & $\begin{array}{l}\text { Sarpr } \\
\text { as }\end{array}$ & $\begin{array}{l}\text { Pengelola } \\
\text { an }\end{array}$ & $\begin{array}{l}\text { Pembiaya } \\
\text { an }\end{array}$ & $\begin{array}{l}\text { Penilaia } \\
\text { n }\end{array}$ \\
\hline 1 & $\left.\mathrm{PME}^{*}\right)$ & & $\mathrm{X}$ & $X$ & & $\mathrm{X}$ & $\mathrm{X}$ & & \\
\hline 2 & MBM (RKM) & $\mathrm{X}$ & $\mathrm{X}$ & $\mathrm{X}$ & $\mathrm{X}$ & & & $\mathrm{X}$ & $\mathrm{X}$ \\
\hline 3 & Hidup Sehat & $\mathrm{X}$ & $\mathrm{X}$ & $\mathrm{X}$ & & $\mathrm{X}$ & $\mathrm{X}$ & & \\
\hline 4 & KTSP2006/K1 & & & & & & & & \\
\hline & 3 & $\mathrm{X}$ & $\mathrm{X}$ & $\mathrm{X}$ & $\mathrm{X}$ & & & & $\mathrm{X}$ \\
\hline 5 & PAIKEM & $\mathrm{X}$ & $\mathrm{X}$ & $\mathrm{X}$ & $\mathrm{X}$ & & & & $\mathrm{X}$ \\
\hline 6 & Perpustakaan & $\mathrm{X}$ & $\mathrm{X}$ & & $\mathrm{X}$ & $\mathrm{X}$ & $\mathrm{X}$ & $\mathrm{X}$ & \\
\hline 7 & $\begin{array}{l}\text { Administrasi } \\
\text { dan Keuangan }\end{array}$ & & $\mathrm{X}$ & & & $\mathrm{X}$ & $\mathrm{X}$ & $\mathrm{X}$ & \\
\hline
\end{tabular}

Sumber: Triangulasi (teknik) dokumen Evaluasi Diri (EDM) dan Rencana Kerja Madrasah (RKM) - MI Bustanul Uqul, MI Raden Patah, dan Madrasah MI Thoriqul Huda (2015), Laporan Akhir Kegiatan Dana Hibah AEPI C3 MI Bustanul Uqul (Australian Aid, 2015a:3-4), Dokumen Laporan Akhir Kegiatan Dana Hibah AEPI C3 MI Raden Patah (Australian Aid, 2015b:3-4), Dokumen Laporan Akhir Kegiatan Dana Hibah AEPI C3 MI Thoriqul Huda (Australian Aid, 2015c:3-4), selanjutnya dilakukan triangulasi teknik dengan wawancara dan observasi oleh Penulis.

Ket *)PME = Pengembangan Madrasah Efektif 


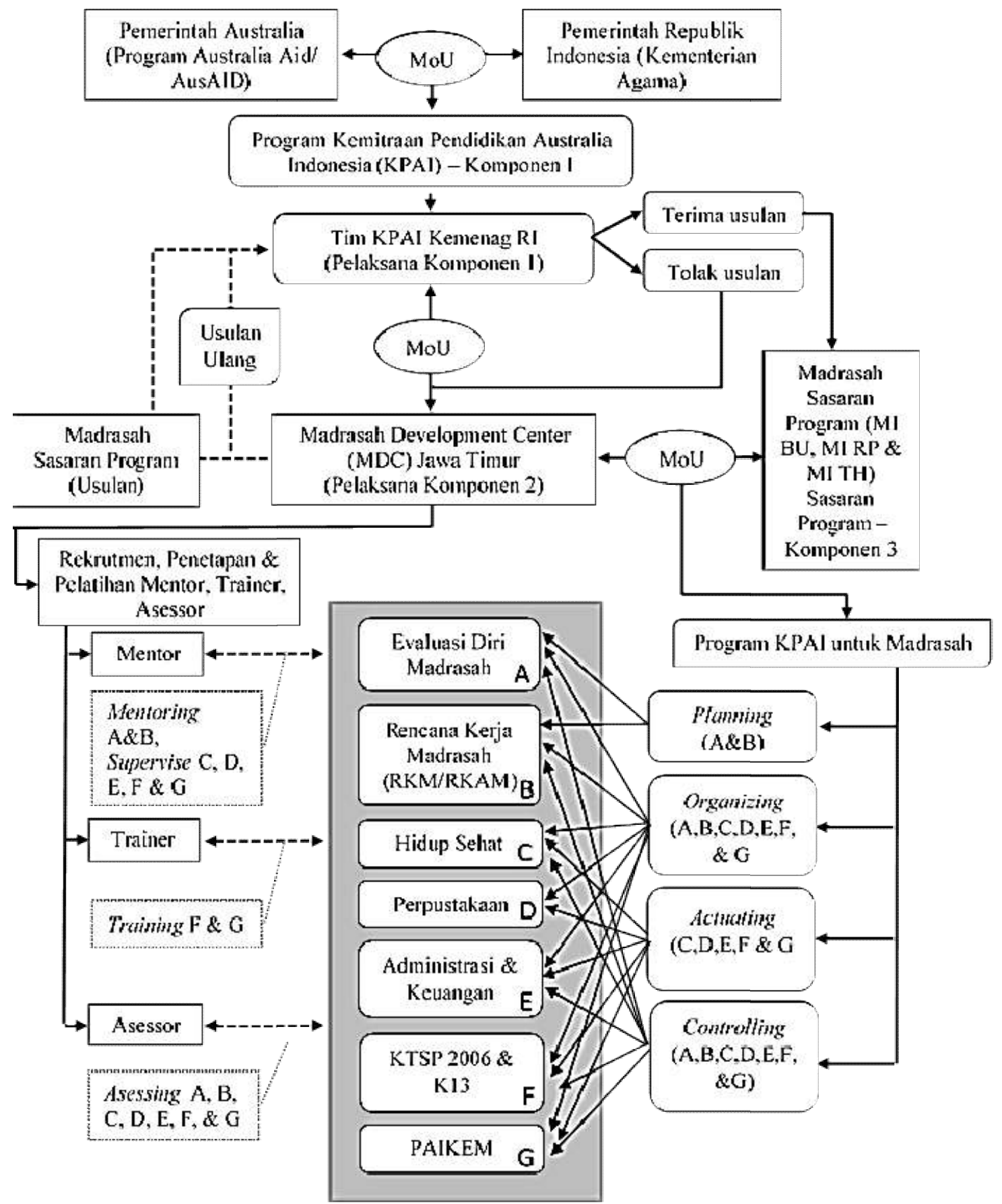

Gambar 1. Konstruksi Manajemen Peningkatan Mutu Madrasah Berbasis Kemitraan

Tritunggal di Madrasah Ibtidaiyah (MI) Bustanul Uqul, MI Raden Patah, dan MI

\section{Thoriqul Huda}

Sumber: Rekonstruki hasil triangulasi (teknik) dokumen Evaluasi Diri (EDM) dan Rencana Kerja Madrasah (RKM) - MI Bustanul Uqul, MI Raden Patah, dan Madrasah MI Thoriqul Huda (2015), Laporan Akhir Kegiatan Dana Hibah AEPI C3 MI Bustanul Uqul (Australian Aid, 2015a:3-4), Dokumen Laporan Akhir Kegiatan Dana Hibah AEPI C3 MI Raden Patah(Australian Aid, 2015b:3-4), Dokumen Laporan Akhir Kegiatan Dana Hibah AEPI C3 MI Thoriqul Huda(Australian Aid, 2015c:3-4), selanjutnya dilakukan triangulasi teknik dengan wawancara dan observasi oleh Penulis. 
Bentuk-bentuk Kegiatan Manajemen Peningkatan Mutu Madrasah Berbasis Kemitraan Tritunggal di Madrasah Ibtidaiyah Bustanul Uqul, Madrasah Ibtidaiyah Raden Patah, dan Madrasah Ibtidaiyah Thoriqul Huda

Berdasarkan pendalaman yang peneliti lakukan, data-data dilapangan menunjukkan bahwa setidkanya ada dua kelompok program yang hendak dilaksanakan melalui Kemitraan Pendidikan Australia-Indonesia (KPAI), yakni: (1) program non-fisik dalam bentuk kegiatan pelatihan-pelatihan (training oleh trainer) disertasi dengan mentoring oleh mentorselama program berlangsung dan penilaian oleh asessor pada saaat program berakhir. Program nonfisik ini sekaligus menjadi program yang paling mendominasi di Madrasah sasaran, (2) program fisik sebagai tambahan program yang diperlukan terutama guna mendorong program hidup sehat, ditambah dengan beberapa program perbaikan dan atau pengadan saranaprasarana pendidikan, baik yang berkaitan dengan pembelajaran maupun kebutuhan kerja sehari-hari bagi para guru dan tenaga kependidikan di madrasah. Kesemuanya dilakukan melalui skema hibah dana, mentoring, dan training.Selanjutnya, temuan tiap situs mengenai kegiatan manajemen peningkatan mutu madrasah berbasis kemitraan tritunggal di Madrasah Ibtidaiyah Bustanul Uqul, Madrasah Ibtidaiyah Raden Patah, dan Madrasah Ibtidaiyah Thoriqul Huda Peneliti sajikan pada tabel 2, tabel 3, dan tabel 4, selanjutnya induksi termodifikasi sebagai temuan lintas situs disajikan pada tabel 5 . 
Tabel 2. Bentuk Kegiatan dalam Kemitraan Tritunggal (Temuan Situs 1, MI Bustanul Uqul).

No Jenis Kegiatan Bentuk Kegiatan

1. Kegiatan Traning dan

a. Penyusunan dan sosialisasi Evaluasi Diri Madrasah

Workshop di Madrasah

(EDM) dan Rencana Kerja Madrasah (RKM)

b. Whorkshop KTSP tahap 2

c. Pelatihan PAIKEM (Pembelajaran Aktif, Inovatif,

Kreatif, Efektif dan Menyenangkan)

d. Bedah Instrumen Akreditasi

2. Pembelian Perlengkapan

a. Pengadaan sarpras kelas

Pembelajaran/Pendidikan

b. Pengadaan alat peraga

c. Pengadaan media pembelajaran

3. Pembelian/Perbaikan

a. Pengadaan sarpras perpustakaan

Peralatan dan Fasilitas

b. Pengadaan tempat cuci tangan

c. Pengadaan peralatan TU

d. Pengadaan sarpras UKS

e. Pembelian alat kesenian

f. Pembelian alat olahraga

g. Pengadaan meja dan kursi guru

h. Pengadaan sarpras koperasi siswa

i. Pengadaan kostum drumband

j. Pengadaan mebeler kelas

4 Perbaikan Bangunan

a. Perbaikan pintu toilet dan pemasangan kran wudhu

Ringan

b. Perbaikan ruang perpustakaan dan UKS

c. Tamanisasi madrasah

d. Renovasi atap kelas

e. Renovasi ruang kepala madrasah, TU, dan ruang guru

f. Pengecatan gedung dan ruang kelas

g. Perbaikan saluran atap

Sumber: Hasil analisis lintas situs dengan teknik induksi termodifikasi melalui Dokumen Laporan Akhir Kegiatan Dana Hibah AEPI C3 MI Bustanul Uqul (Australian Aid, 2015a:3-4) selanjutnya dilakukan triangulasi teknik dan sumber melalui wawancara dan observasi oleh Penulis (2016). 
Tabel 2. Bentuk Kegiatan dalam Kemitraan Tritunggal (Temuan Situs 2, MI Raden

Patah).

\begin{tabular}{lll}
\hline No & \multicolumn{1}{c}{ Jenis Kegiatan } & \multicolumn{1}{c}{ Bentuk Kegiatan } \\
\hline 1. & Kegiatan Traning dan & a. Penyusunan dan Sosiasialisasi Rencana Kerja \\
& Workshop di Madrasah & Madrasah (RKM) \\
& & b. Workshop KTSP dan K13 \\
& c. Pelatihan PAIKEM (Pembelajaran Aktif, Inovatif, \\
& Kreatif, Efektif dan Menyenangkan) \\
& d. Pelatihan simulasi akreditasi \\
& e. Pelaporan Akhir
\end{tabular}

2. Pembelian Perlengkapan a. Pembelian alat peraga pembelajaran

Pembelajaran/Pendidikan b. Pembelian alat olahraga

c. Pembelian alat pemadan kebakaran

d. Pembelian papan data

e. Pembelian media elektronik

f. Pembelian perlengkapan kelas

g. Pembelian almari kelas

3. Pembelian/Perbaikan

a. Pembelian komputer dan Printer TU

Peralatan dan Fasilitas

b. Pembelian dan peningkatan sarana dan prasarana perpustakaan

c. Pembelian/ pengadaan sarana dan prasarana UKS

d. Pembelian pengadaan peralatan TU

4. Perbaikan Bangunan

a. Renovasi toilet

Ringan

b. Pengecatan gedung dan ruang kelas

c. Pengadaan tempat cuci tangan

d. Renovasi taman

e. Pengadaan kantin sehat

f. Renovasi ruang kepala Madrasah, TU dan guru

g. Renovasi pintu gerbang/joglo

h. Renovasi atap ruang guru dan dapur

i. Renovasi ruang perpustakaan

j. Renovasi jendela kelas

k. Pembuatan papan nama madrasah

1. Pengembangan taman

Sumber: Hasil analisis lintas situs dengan teknik induksi termodifikasi melalui Dokumen Laporan Akhir Kegiatan Dana Hibah AEPI C3 MI Bustanul Uqul (Australian Aid, 2015b:3-4), selanjutnya dilakukan triangulasi teknik dan sumber melalui wawancara dan observasi oleh Penulis (2016). 
Tabel 3. Bentuk Kegiatan dalam Kemitraan Tritunggal (Temuan Situs 3, MI Thoriqul Huda).

\begin{tabular}{|c|c|c|}
\hline No & Jenis Kegiatan & Bentuk Kegiatan \\
\hline 1. & $\begin{array}{l}\text { Kegiatan Traning dan } \\
\text { Workshop di Madrasah }\end{array}$ & $\begin{array}{l}\text { a. Penyusunan Rencana Kerja Madrasah (RKM) dan } \\
\text { sosialisasi RKM } \\
\text { b. Pelatihan PAIKEM (Pembelajaran Aktif, Inovatif, } \\
\text { Kreatif, Efektif dan Menyenangkan) } \\
\text { c. Pelatihan kurikulum tahap dua } \\
\text { d. Pelatihan simulasi akreditasi }\end{array}$ \\
\hline 2. & $\begin{array}{l}\text { Pembelian Perlengkapan } \\
\text { Pembelajaran/Pendidikan }\end{array}$ & $\begin{array}{l}\text { a. Pembelian mebel almari TU, } \\
\text { b. Pembelian mebel perpustakaan (meja kursi komputer, } \\
\text { computer, meja baca, rak buku, rak majalah, lemari } \\
\text { lab IPA) } \\
\text { c. Pembelian alat elektronik (kamera digital dan LCD) } \\
\text { d. Pembelian alat peraga (poster edukatif, peta, globe, kit } \\
\text { IPA, kit MTK, kaca pembesar, termometer) } \\
\text { e. Pembelian alat olah raga } \\
\text { f. Pembelian perlengkapan UKS } \\
\text { g. Pengadaan perlengkapan sekolah (sapu dan alat pel) }\end{array}$ \\
\hline 3. & $\begin{array}{l}\text { Pembelian/Perbaikan } \\
\text { Peralatan dan Fasilitas }\end{array}$ & $\begin{array}{l}\text { a. Pembelian mebel (kursi, bangku) bagi peserta didik } \\
\text { b. Pembelian perlengkapan kantin (etalase) } \\
\text { c. Pembelian alat pendukung pembelajaran (papan tulis, } \\
\text { papan mading) } \\
\text { d. Pembelian alat kesenian (drumband) } \\
\text { e. Pembelian tempat duduk cor }\end{array}$ \\
\hline 4. & $\begin{array}{c}\text { Perbaikan Bangunan } \\
\text { Ringan }\end{array}$ & $\begin{array}{l}\text { a. Renovasi toilet } \\
\text { b. Renovasi pagar } \\
\text { c. Perbaikan atap ruang kelas V dan VI } \\
\text { d. Pengadaan alat cuci tangan } \\
\text { e. Tamanisasi madrasah } \\
\text { f. Penyekat ruang perpustakaan } \\
\text { g. Pengecatan ruang kelas }\end{array}$ \\
\hline
\end{tabular}

Sumber: Hasil analisis lintas situs dengan teknik induksi termodifikasi melalui Dokumen Laporan Akhir Kegiatan Dana Hibah AEPI C3 MI Thoriqul Huda (Australian Aid, 2015c:3-4), selanjutnya dilakukan triangulasi teknik dan sumber melalui wawancara dan observasi oleh Penulis (2016). 
Tabel 4. Temuan Lintas Situs dan Refleksi Bentuk Kegiatan dalam Kemitraan

Tritunggal.

\begin{tabular}{|c|c|c|c|c|}
\hline No & $\begin{array}{r}\text { Jeni } \\
\text { Kegia }\end{array}$ & & $\begin{array}{c}\text { Analisis Lintas Situs (Induksi } \\
\text { Termodifikasi) }\end{array}$ & Refleksi \\
\hline 1. & 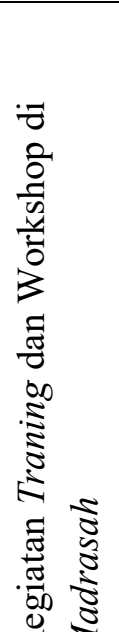 & 1) & $\begin{array}{l}\text { Penyusunan dan sosialisasi Evaluasi Diri } \\
\text { Madrasah (EDM), Rencana Kerja } \\
\text { Madrasah (RKM), dan sosialisasi RKM } \\
\text { Workshop KTSP dan K13 Sebanyak } 2 \\
\text { tahap } \\
\text { Pelatihan PAIKEM (Pembelajaran Aktif, } \\
\text { Inovatif, Kreatif, Efektif dan } \\
\text { Menyenangkan) } \\
\text { Pelatihan simulasi dan bedah instrumen } \\
\text { akreditasi } \\
\text { Pendampingan penyusunan laporan akhir } \\
\text { oleh Madrasah }\end{array}$ & $\begin{array}{l}\text { Kegiatan ini berfokus pada } \\
\text { penguatan kapasitas personil } \\
\text { madrasah. Pelatihan dan } \\
\text { pedampingan yang } \\
\text { dilakukan memberikan } \\
\text { manfaat langsung pada } \\
\text { penguatan standar isi, } \\
\text { standar proses, standar } \\
\text { pendidik dan tenaga } \\
\text { kependidikan, standar } \\
\text { pengelolaan, dan standar } \\
\text { penilaian }\end{array}$ \\
\hline 2. & 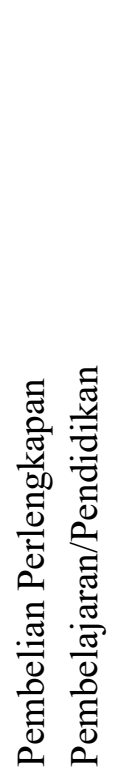 & 1) & $\begin{array}{l}\text { Pengadaan sarana-prasarana kelas yang } \\
\text { mencakup papan data dan almari kelas } \\
\text { Pengadaan alat peraga pembelajaran } \\
\text { (poster edukatif, peta, globe, kit IPA, kit } \\
\text { MTK,kaca pembesar, termometer) dan } \\
\text { alat olahraga } \\
\text { Pembelian alat elektronik (kamera digital } \\
\text { dan LCD) } \\
\text { Pembelian sarana-prasarana sekolah } \\
\text { lainnya yang mencakup kelengkapan } \\
\text { UKS, perlengkapan kebersihan, mebeler } \\
\text { kantor, dan mebeler perpustakaan (meja } \\
\text { kursi komputer, computer, meja baca, rak } \\
\text { buku, rak majalah, lemari lab IPA) }\end{array}$ & $\begin{array}{l}\text { Kegiatan ini lebih } \\
\text { merupakan bagian dari } \\
\text { program hidup sehat namun } \\
\text { diperluas dengan beberapa } \\
\text { tambahan untuk } \\
\text { meningkatkan mutu sarana } \\
\text { prasarana pendidikan dan } \\
\text { pembelajaran(standar sarana } \\
\text { dan prasarana) guna } \\
\text { menciptakan daya dukung } \\
\text { lingkungan belajar yang } \\
\text { sehat sekaligus mendorong } \\
\text { peningkatan efektivitas } \\
\text { pembelajaran. }\end{array}$ \\
\hline
\end{tabular}


1) Pembelian dan peningkatan sarana dan prasarana perpustakaan

2) Pengadaan tempat cuci tangan

3) Pembelian mebeler kelas (kursi peserta didik, bangku peserta didik, meja guru, kursi guru, papan tulis, dan papan mading)

4) Pengadaan peralatan TU (PC set dan printer)

3.

5) Pengadaan sarpras UKS

6) Pembelian alat kesenian (alat drumband dan kostum)

7) Pembelian alat olahraga

8) Pengadaan meja dan kursi guru

9) Pengadaan sarpras koperasi siswa dan kantin

10)

ngadaan kostum drumband

11)

ngadaan mebeler

12)

mbelian tempat duduk cor

1) Renovasi toilet (perbaikan pintu dan pemasangan kran wudhu)

2) Renovasi gedung (pengecatan ruang kelas, ruang kepala madrasah, TU, ruang guru, ruang kelas, renovasi atap, renovasi dapur, renovasi ruang perpustakaan)

3) Pengadaan tempat cuci tangan

4) Renovasi taman dan gerbang sekolah

5) Pengadaan kantin sehat

6) Pembuatan papan nama madrasah

7) Pengembangan taman
Dalam laporan akhir mentor di ketiga madrasah memang terpisah dalam kelompok yang berbeda, namun peneliti melihat bahwa kelompok program yang ketiga ini sama dengan kelompok yang kedua, hanya komponen pengadaan sarana prasarananya yang lebih kompleks dibanding kelompok yang kedua. Keterkaitan terhadap penguatan SNP, cukup jelas, yakni pada standar sarana dan prasarana sebagaimana Pe kelompok kedua.

Sama dengan refleksi kelompok kedua, kelopok yang keempat ini juga tersaji dalam kelompok yang berbeda dengan kelompok dua dan tiga meskipun memiliki keserupaan. Keterkaitan terhadap penguatan SNP, cukup jelas, yakni pada standar sarana dan prasarana sebagaimana kelompok kedua.

Sumber: Hasil analisis lintas situs dengan teknik induksi termodifikasi melalui sumbersumber Dokumen Laporan Akhir Kegiatan Dana Hibah AEPI C3 MI Bustanul Uqul (Australian Aid, 2015a:3-4), Dokumen Laporan Akhir Kegiatan Dana Hibah AEPI C3 MI Raden Patah (Australian Aid, 2015b:3-4), Dokumen Laporan Akhir Kegiatan Dana Hibah AEPI C3 MI Thoriqul Huda (Australian Aid, 2015c:3-4), dilakukan triangulasi teknik dan sumber melalui wawancara dan observasi oleh Penulis. 


\section{DISKUSI DAN PEMBAHASAN}

Akreditasi, selain sebagai sasaran akhir yang hendak dicapai melalui program tritunggal yang digagas Kemitraan Pendidikan Australia Indonesia (KPAI), sesungguhnya juga merupakan bagian penting dari upaya menilai keberhasilan program kemitraan tritunggal yang berlangsung selamasatu tahun lebih. Melalui endline program asessment dengan menghadirkan asessor independen yang direkrut secara terbuka oleh Madrasah Development Center (MDC) selaku pengelola di tingkat distrik, diharapkan akan diperoleh hasil yang objektif untuk menakar keefektifan kemitraan tritunggal sebagai model stimulasi peningkatan mutu madrasah. Proses asessment yang didalamya diisi kegiatan bedah instrumen dan simulasi akreditasi ini sekaligus menjadi program persiapan untuk akreditasi oleh Badan Badan Akreditasi Sekolah/Madrsah (BAN S/M).

Akreditasi oleh BAN S/Mitu sendiri adalah tolok ukur kelayakan (mutu) penyelenggaraan pendidikan oleh satuan pendidikan oleh sekolah maupun madrasah di Indonesia. hal ini sebagaimana diamanatkan dalam Undang-Undang Nomor 20 tahun 2003 tentang Sistem Pendidikan Nasional maupun Peraturan Menteri Pendidikan Nasional Nomor 12 tahun 2009, setiap lembaga pendidikan diwajibkan untuk mengikuti proses akreditasi, yaitu penilaian terhadap kelayakansebuah lembaga pendidikan untuk menyelenggarakan proses pendidikan (belajar mengajar). Ini berarti bahwa akreditasi merupakan parameter resmi untuk mengukur kualitas layanan pendidikan di lembaga pendidikan, termasuk madrasah.

Aspek penilaian kelayakan yang dilakukan mencakup 8 komponen yang disebut dengan standar nasional pendidikan, ini sekaligus menjadi komponen penentu sekolah standar nasional yang juga berlaku bagi madrasah.Pola ini sesungguhnya selaras dengan definisi mutu pendidikan yang digagas oleh UNICEF bahwa peninjauan literatur penelitian yang berkaitan dengan kualitas pendidikan haruslah mencakup definisi yang lebih luas yang melibatkan peserta didik, konten, proses, lingkungan dan hasil (UNICEF, 2000:2).

Implementasi berbagai program yang diawali dari evaluasi diri madrasah (EDM) dan selanjutnya diikuti penyusunan Rencana Kerja Madrasah (RKM) sebagai acuan, sesungguhnya menjadi guide yang komprehensif penyelenggaraan berbagai program (utamanya non-fisik) melalui skema kemitraan tritunggal pendanaan-mentoring-training dalam satu paket yang terintegrasi. Peneliti melihat bahwa ketujuh jenis mentoring/pelatihan sebagaimana tersaji dalam tabel 1 dan selanjutnya melahirkan berbagai bentuk kegiata sebagaimana tersaji dalam tabel 2, tabel 3 dan tabel 4 sesungguhnya memberikan gambaran yang cukup lengkap, dimana program-program tersebut telah menyentuh kedelapan standar nasional pendidikan (SNP). Dalam redaksi yang berbeda, Peneliti dapat maknai pula bahwa program-program tersebut sejatinya telah menyentuh berbagai elemen madrasah, mulai dari 
peserta didik, pendidik, tenaga kependidikan, maupun lingkungan pembelajaran yang sehat dan mendukung terciptanya pembelajaran yang efektif.

Ulfiah menemukan bahwa, program-program pelatihan yang berhubungan dengan pengembangan madrasah efektif dalam KPAI di jawa barat nyatanya memiliki efektifitas yang baik. Hal ini dibuktikan dengan peningkatan nilai post test berdasarkan pretest, dengan perubahan pengetahuan pada peserta dengan effect size yang cukup bagus. Secara keseluruhan dapat dinyatakan bahwa tingkat relevansi dan efektifitas pelatihan Pengembangan Madrasah Efektif sangat tinggi. Hal ini dibuktikan dengan angka pencapaian indeks relevansi melebihi $80 \%$, juga dibuktikan oleh rata-rata pencapaian pemenuhan output tagihan dengan nilai 85,35\%. Meski perlu pembuktian kuantitatif lebih lanjut, setidaknya temuan ulfiah tersebut dapat digeneralisir pada tiga situs Penelitian ini(2016:221233).

Sebaran program yang komprehensif dalam peningkatan mutu madrasah tersebut selaras dengan pernyataan Adams (1993) dalam UNICEF(2000:4) bahwa pendidikan yang berkualitas mencakup 5 komponen: (1) Peserta didik yang sehat, bergizi baik dan siap untuk berpartisipasi dan belajar, dan didukung dalam pembelajaran oleh keluarga dan komunitas mereka, (2) Lingkungan yang sehat, aman, pelindung dan peka gender, serta menyediakan sumber daya dan fasilitas yang memadai, (3) Konten yang tercermin dalam kurikulum yang relevan dan bahan untuk kemahiran keterampilan dasar, terutama di bidang literasi, berhitung dan keterampilan untuk hidup, dan pengetahuan di bidang-bidang seperti jenis kelamin, kesehatan, gizi, HIV/AIDS dan perdamaian, (4) Proses pembelajaran guru menggunakan pendekatan pengajaran yang berpusat pada anak, di kelas dan sekolah yang dikelola dengan baik dan keterampilan penilaian yang memadai untuk memfasilitasi pembelajaran sekaligus mengurangi kesenjangan, dan (5) Hasil yang mencakup pengetahuan, keterampilan dan sikap, dan terkait dengan tujuan nasional untuk pendidikan dan partisipasi positif dalam masyarakat.

Senada dengan hal tersebut, Mayer, Mullens, Moore, dan Ralph dalam National Center For Education Statistics - U.S. Department of Education, melalui Office of Educational Research and Improvement (2000:5-44) merilis bahwa ada tiga pilar sekolah berkualitas: (1) guru (kecakapan akademik, penguasaan materi, dan pengalaman guru serta pengembangan profesi), (2) kelas (materi pembelajaran, strategi pembelajaran, teknologi, dan ukuran kelas), dan (3) sekolah (kepemimpinan, tujuan, komunitas profesional, disiplin, dan lingkungan akademik). Meskipun dengan intensitas yang berbeda, pilar-pilar tersebut beserta komponen yang ada didalamnya ternyata juga Peneliti temui dalam berbagai bentuk kegiatan yang digagas dalam peningkatan mutu madrasah melalui kemitraan tritunggal di MI Bustanul Uqul, MI Raden Patah, dan MI Thoriqul Huda. 
Pembangunan mutu madrasah melalui skema kemitraan model tritunggal ini ideal karena madrasah diberi pembekalan (melalui pelatihan), kemudian melakukan tindak lanjut dengan didukung dana yang ada, serta perkembangannya dimonitor melalui pendampingan dan kunjungan oleh mentor. Namun demikian, telah ditegaskan pula dimuka bahwa program KPAI melalui skema tritunggal ini hanyalah lesson learn, piloting, ataupun stimulan awal dengan harapan agar setelah program berakhir dimana pelatihan dan pendampingan juga selesai, diharapkan ada transfer belajar yang positif. Budaya mutu maupun peningkatan kemampuan dan keterampilan pengelolaan madrasah melalui hasil pelatihan dan mentoring diharapkan dapat terus dilanjutkan secara mandiri oleh madrasah.

Dalam konteks ini, tentu pada gilirannya kembali pada spirit manajemen berbasis madrasah (MBM). Berkenaan dengan MBM tersebut, otoritas, kreativitas, pemahaman personil terhadap MBM, adalah beberapa dimensi kunci dari temuan penelitian Muhajir mengenai praktik MBS di MAN 1 dan MAN 2 Serang (2016:50-60). Faktor personil ini juga berkesesuaian dengan temuan Kaluge, Setiasih, dan Tjahjono (2004: 36) bahwa kreativitas guru adalah faktor kunci dalam mensiasati keterbatasan alat peraga dan alokasi dana untuk pembeliannya, disamping diskusi kolegial antar sesama guru dan dengan kepala sekolah sebagai spirit peningkatan mutu berbasis sekolah yang dapat mendorong guru membuat pembelajaran yang lebih sistematis.

Tantangan ke depan bagi madrasah sasaran adalah mereka harus mempertahankan kualitas yang sudah dicapai selama menjadi sasaran program kemitraan dan didampingi oleh mentor. Praktisnya, madrasah harus menyusun target untuk mencapai level dan kualitas yang lebih baik dibanding kondisi saat ini, pada periode tertentu di waktu mendatang. Kualitas yang ideal tidak pernah ada terminal akhirnya, karena ketika target yang direncanakan dapat tercapai maka madrasah harus menetapkan target yang lebih tinggi lagi.RKM harus terus direview sesuai dengan perubahan dan tuntutan zaman.Sehingga, madrasah memiliki daya saing dan keunggulan yang up-to-date, tidak lagi jadul.

Sampai dengan berakhirnya program kemitraan, setidaknya Kementerian Agama, MDC, dan masing-masing madrasah sasaran telah mendapatkan best practice mengenai partnership yang efektif dan produktif dalam mengawal peningkatan mutu madrasah. Namun demikian, tantangan yang tidak kalah berat adalah pasca berakhirnya program, yakni berkaitan dengan tingkat ketergantungan madrasah terhadap berbagai (program) bantuan. Tholcah menyebut (2016:39) bahwa Madrasah sering kali berharap, setelah program kemitraan ini berakhir, Kementerian Agama dan Australia menginisiasi program lainnya di mana mereka kembali berharap dijadikan sasaran. Kenyataan ini juga terkonfirmasi dalam wawancara Peneliti dengan Kepala Madrasah ketiga situs penelitian. Pola pikir yang demikian 
inilahyang perlu dihilangkan dari madrasah sasaran karena seluruh personil sebenarnya telah dibekali kemampuan manajemen administrasi, pengelolaan keuangan, kepemimpinan, pengembangan dan penguatan jaringan, serta peningkatan kapasitas pengelolanya. Maka sikap-sikap kebergantungan yang demikian cenderung masalah mental kemandirian.

Maka, madrasah-madrasah sasaran kemitraan tritunggal idealnya memiliki kesiapan untuk mandiri dalam mengelola madrasahnya. Hal ini dapat dilakukan dengan mengoptimalkan segenap potensi sumber daya yang ada di internal masing-masing madrasah sekaligusdukungan stakeholder dan jaringan yang sudah dibangun oleh madrasah sendiri. Hal ini memang bukanlah tugas yang ringan, namun dengan kebersamaan komitmen dari seluruh stakeholder madrasah dari tingkat pusat, distrik dan terutama di tingkat madrasah itu sendiri bukan tidak mungkin hal itu dapat tercapai. Program kemitraan pendidikan dengan skema tritunggal ini sekali lagi hanyalah salah satu upaya stimulasi dalam kerja besar memajukan madrasah.

\section{E. SIMPULAN}

Pemerintah Australia melalui program Asutralia Aid mengagas kerjasama dengan Kementerian Agama Republik Indonesia yang selanjutnya melahirkan program Kemitraan Pendidikan Australia Indonesia (KPAI) yang berorientasi pada peningkatan mutu madrasah melalui skema hibah pendanaan, mentoring, dan pelatihan secara terintegrasi yang kemudian disebut sebagai tritunggal. Dalam prosesnya, Madrasah Ibtidaiyah (MI) Bustanul Uqul, MI Raden Patah, dan MI Thoriqul Huda sebagai bagian dari madrasah sasaran program diberikan support dana sebesar AUS\$10.000 atau sebesarRp 100.000.000,00yang dicairkan dalam tiga tahap, yaitu \$ 1000 setelah penandatanganan kontrak sebagai madrasah sasaran, \$7000 setelah proposal penggunaan disetujui oleh komponen 3, serta \$2,000 dicairkan setelah laporan penggunaan dana yang dua tahap disetujui. Adapun program-program yang digulirkan lebih banyak diperuntukkan bagi program non-fisik untuk meningkatkan mutu personil madrasah yang mencakup tujuh komponen: Pengembangan Madrasah Efektif (PME) dan Manajemen Berbasis Madrasah (MBM) yang selanjutnya melahirkan program pendampingan (mentoring) penyusunan Evaluasi Diri Madrasah (EDM) dan Rencana Kerja Madrasah (RKM).

Muara dari program ini adalah tercapainya peningkatan mutu madrasah dan kesiapan akreditasi sebagai sasaraannya. Untuk mencapainya, melalui skema yang sama selanjutnya dilaksanakan berbagai pelatihan dan pendampingan lanjutan berupa program hidup sehat (UKS, Sanitasi, penataan taman, perwujudan tolet bersih dan lingkungan sekolah sehat), penyusunan dan pengembangan kurikulum madrasah (KTSP 2006 dan K13), PAIKEM 
(Pembelajaran Aktif, Kreatif, InovatiF dan Menyenangkan), perogram peningkatan kapasitas perpustakaan, serta pengelolaan adinistrasi dan keuangan madrasah. Ukuran keberhasilan program sekaligus sebagai persiapan akreditasi dilaksanakan melalui asessment terhadap end line program oleh Asessor independen yang ditunjuk dan dikontrak oleh MDC sebagai pengelola program di tingkat distrik.

Namun demikian, dalam prakteknya, madrasah juga diberikan ruang untuk menggulirkan program-program fisik guna mendukung program-program non-fisik sesuai skala prioritas yang ditetapkan dalam RKM yang telah disusunSkema ini diharapkan dapat menjadi lesson learn atau best practice model kemitraan yang dapat membantu madrasah untuk memiliki kemampuan dan kemandirian dalam perwujudan manajemen peningkatan mutu berbasis madrasah di masa-masa yang akan datang pasca program selesai dilaksanakan. 


\section{DAFTAR PUSTAKA}

Australian Aid. Laporan Akhir Kegiatan Dana Hibah AEPI C3 MI Bustanul Uqul. Malang: Madrasah Ibtidaiyah Bustanul Uqul. 2015a

Australian Aid. Laporan Akhir Kegiatan Dana Hibah AEPI C3 MI Raden Patah. Malang: Madrasah Ibtidaiyah Raden Patah. 2015b

Australian Aid. Laporan Akhir Kegiatan Dana Hibah AEPI C3 MI Thoriqul Huda. Malang: Madrasah Ibtidaiyah Thoriqul Huda. 2015c

Buna'i.Peningkatan Mutu Madrasah(Analisis Keefektifan Manajemen Peningkatan Mutu Berbasis Madrasah). Tadrîs. Volume 1. Nomor 2, 2006.

Kepala Badan Penelitian dan Pengembangan Departemen Agama Republik Indonesia. Hasil Survey Pengelolaan Madrasah Jakarta: Departemen Agama Republik Indonesia Badan Penelitian dan Pengembangan. 2010.

Kaluge, Laurens., Setiasih., dan Tjahjono, Harjanto. The Quality Improvement of Primary Children Learning through a School-Based Programme in Indonesia. Research Paper Universitas Surabaya. 2004.

Mayer, Daniel P., Mullens., John E., Moore, Mary T.,dan Ralph,John. Monitoring School Quality: An Indicators Report, NCES 2001-030.Washington, DC: .S. Department of Education. National Center for Education Statistics. 2000.

Muhajir. The Implementation of Madrasah-Based Management (MBM) at MAN 1 and MAN 2 Serang City, Banten, Indonesia-A Comparative Study. Higher Education Studies; Vol. 6, No. 2; 2016. 2016.

Office of Educational Research and Improvement. Statistical Analysis Report - December 2000 - MonitoringSchool Quality:An Indicators Report. Office of Educational Research and Improvement - National Center For Education Statistics, U.S. Department of Education. 2000.

Risasta, Bella. Motivasi Australia Memberikan Bantuan Pendidikan Kepada Madrasah Di Indonesia Melalui Program AusAID Tahun 2011-2014. JOM - FISIP Universitas Riau Vol. 2 No. 2 -Oktober 2015. 2015.

Setiawan, M. Nur Kholis. Mengakali Takdir Madrasah. Dalam Majalah PENDIS Pendidikan Islam, Edisi No. 2/II/2014. Jakarta: Kementerian Agama Republik Indonesia. 2014.

Tholchah, Muchammad. Kemitraan Australia-Indonesia untuk Peningkatan Mutu Madrasah. Dalam Zada, Khamami. 2015. Majalah PENDIS - Pendidikan Islam .Edisi No. 5/III/ 2015. Jakarta: Kementerian Agama Republik Indonesia. 2015. 
Tholchah, Muchammad. 2016. Kemitraan untuk Peningkatan Mutu Madrasah. Dalam Ghufron, Achmad (Eds.). 2016. Majalah Ikhlas Beramal Edisi 97 Tahun XIX JanuariMaret 2016.

Ulifiah. 2016. Efektifitas dan Relevansi Pelatihan Pengembangan Madrasah Efektif pada Program AusAid SNIP MDC Jawa Barat. Edukasi, Volume 04, Nomor 02, November 2016: 221-233.

UNICEF. 2000. Defining Quality in Education. A paper presented by UNICEF at the meeting of The International Working Group on Education Florence, ItalyJune 2000.

.Undang-Undang Republik Indonesia No. 20 Tahun 2003 tentang Sistem Pendidikan Nasional. Jaringan Dokumentasi dan Informasi Hukum Badan Pemeriksa Keuangan Republik Indonesia. (Online), (http://www.jdih.bpk.go.id), diakses 13 September 2016 